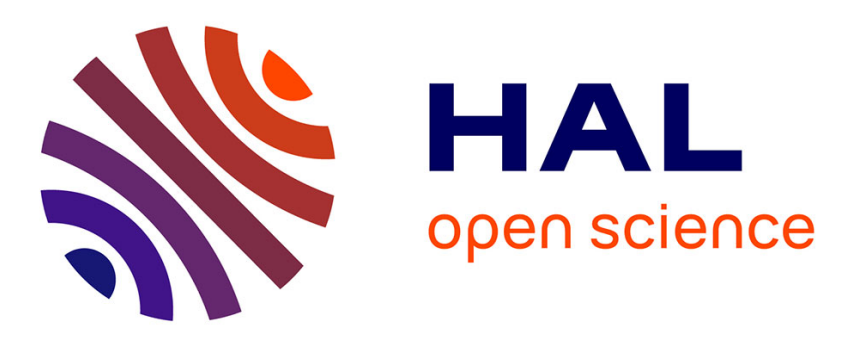

\title{
Making Legibility between Colony and Empire: Translation, Conflation, and the Making of the Muslim State
}

Iza Hussin

\section{- To cite this version:}

Iza Hussin. Making Legibility between Colony and Empire: Translation, Conflation, and the Making of the Muslim State. Kimberly J. Morgan; Ann Shola Orloff. The Many Hands of the State. Theorizing Political Authority and Social Control, Cambridge University Press, pp.349-368, 2017, 978-1316501139. 10.1017/9781316471586.015 . halshs-03158008

\section{HAL Id: halshs-03158008 \\ https://shs.hal.science/halshs-03158008}

Submitted on 3 Mar 2021

HAL is a multi-disciplinary open access archive for the deposit and dissemination of scientific research documents, whether they are published or not. The documents may come from teaching and research institutions in France or abroad, or from public or private research centers.
L'archive ouverte pluridisciplinaire HAL, est destinée au dépôt et à la diffusion de documents scientifiques de niveau recherche, publiés ou non, émanant des établissements d'enseignement et de recherche français ou étrangers, des laboratoires publics ou privés. 


\title{
Making Legibility between Colony and Empire
}

\author{
Translation, Conflation, and the Making \\ of the Muslim State
}

\author{
Iza Hussin
}

What does it mean to see like a state? James Scott's important and powerful Seeing Like a State locates the vantage point of the high modernist state far above those it seeks to order, govern, and alter, and makes clear that seeing like a state begins not with the act of seeing, but with efforts to render legible the incomprehensibility and unpredictability of everyday life. "Legibility is a condition of manipulation," and making legibility has long been at the core of the modern state. ${ }^{\mathrm{I}}$ Yet, looking beyond the totalitarian and monolithic panoramas of the high modernist state, it is possible to see that the effort to render legibility has not only been a top-down project, but is also an effort undertaken from below; legibility may indeed be a condition of manipulation, but it also confers benefits for those positioned to receive them. Through the lens of British colonial law, this chapter explores the making of legibility from two perspectives: that of Indian Muslim judges positioned between the colonial state and Indian Muslim society, seeking to deliver justice within the local context, and that of the imperial system, seeking to make sense of Islam and Muslim life at the end of the nineteenth century. The first rearticulated the place of Islam within colonial law; the second located Islam within a hierarchy and logic of imperial law in which elements of life seen as religious would be relegated to the realm of the private and the family. To see like a state, this chapter shows, more often than not involves translative and comparative work at many levels of abstraction. The ubiquity of translative and comparative dynamics in the work of the state suggests a need to envision the many hands of the state as informing the ways in which the state produced information, interpreted concepts and categories, and pronounced justice - many eyes, many optics, many voices. 
Scholarship on the colonial state has long grappled with the question of the colonial state's ability to project its power from metropole to colony, seeking to understand the extent to which the colonial project imposed order, hierarchy, and difference from the center, despite its basic insufficiencies of military force, administrative capacity, and political legitimacy. ${ }^{2}$ In the arena of colonialism and religion, where these insufficiencies were particularly dire, scholars have tended to emphasize the way in which the colonial state produced order and subjectivity, with religion itself becoming one department of the state among many. ${ }^{3}$ Scholars working on secularism and the state have recently argued that when states define religion, they necessarily also order and confine it. ${ }^{4}$ In these accounts, the state's ability to define, label, arrange, and order has generally been understood as an established part of its toolkit. ${ }^{5}$ These tools, it is also understood, tend to have been applied toward the building of a unified vision and pattern extending uniformly across its domains, subservient to state ideological and political-economic concerns. ${ }^{6}$ The state's unity of purpose, as well as its ability to enforce conformity to this purpose among the human actors and institutional complexes that comprise the state, remains a largely underexamined assumption.

This chapter seeks to examine the work of the British colonial state as it passed through the hands of its "native" middlemen in India - agents chosen to do the work of the state whose utility lay precisely in their position between state and subjects, whose local knowledge was undisputed, and whose positions "in between" required them to do crucial translative and comparative work between British and native societies. The work of these actors, both part of the colonial state and critically apart from it, unsettles the idea that the colonial state was able to seamlessly deliver policy outcomes as articulated at the top of the imperial hierarchy. Not only that, native middlemen such as the Indian Muslim judge at the center of this story worked to rearticulate the goals and meaning of colonial law to itself. In other words, the state's ability to define, label, arrange, and order - to make legibility - came not simply from the top or from the metropole, but was conditioned and altered from within the processes by which it ruled, and the strategic choices of the actors upon which it relied to rule. The colonial state, heavily dependent on the role of intermediaries and middlemen, presents many opportunities for empirical study of these dynamics, but these dynamics are omnipresent in state structures, and indicate rich ground for further exploration (see Chapter 4 for a study of how contemporary nonstate actors render economies legible to investors). ${ }^{7}$ 
The second half of the nineteenth century saw epistemic and political processes through which both local and colonial elites sought comparability and ubiquity, processes with trans-regional and trans-imperial reach. The late nineteenth century saw the emergence of newly capacious categories of law, not just in India, but across empires and continents personal status law, family law, religious law, customary law. These became indispensable components of the modern state's tool chest, but were neither wholly state inventions nor durable legacies from the past. In concluding, I present an argument for further exploration and investigation - that the dynamics of translation, comparison, and mediation that we see in cases such as Ramzan, in the following, lent themselves to powerful and productive imperial conflations - between Islamic law and personal status law, between family law and the law of the private sphere, among others - whose legacies endure in the contemporary state.

\section{TRANSLATION AND CONFLATION: FROM THE COLONIAL TO THE IMPERIAL}

The two perspectives on legibility offered in this chapter - that of native judges in colonial courts, and that of developing categories of law across the British Empire - highlight differences between the ways that the colonial and the imperial state worked toward making legibility. The role of native intermediaries in multiple domains of the state marks the existence and importance of spaces of difference within empires and colonies. As Steinmetz observes, critical analytic and empirical questions remain as to the "distinct species of symbolic capital" involved in these spaces, the struggles they engendered, and the particularities of each of these microfields. ${ }^{8}$ Steinmetz argues, "even where native authorities controlled some aspects of decision making they operated according to customary legal codes approved by the foreign authorities"; ${ }^{9}$ this chapter suggests that the symbolic economy of colonial legal spheres required the presence of native judges, whose position in between led to systematic and iterated renegotiations of the very rules of the colonial game. Yet the nature of the symbolic capital controlled by these native actors - not functionaries of the state, not executors of policy, but active interpreters and makers of the rules of the colonial state - was over time to quite radically alter the workings and meanings of Islam in colonial law, and networks and strategies among actors across the empire would contribute to the redefinition of "Muslim" and Islamic law. 
As Morgan and Orloff argue in the Introduction to this volume, the state project is multiple and contradictory; these spaces of difference and the agents whose work defined and bridged them were many, even common, in the colonial state. The binding of "subjects into their own subjection," to which Morgan and Orloff refer, involves give and take by both the state and its subjects, and this essay seeks to further explore the agency of the state by thinking about the work its agents do as interlocutors between communities and the state. ${ }^{\mathrm{IO}}$ In the colonial courts of British India, for example, a key element of this work was to translate local particularity into idioms recognizable to the British legal system. One outcome of this translative work was to describe Indian Muslims in terms familiar to Anglican Christians. The work of achieving imperial legibility, on the other hand, while relying upon knowledge gained from colonial settings, also involved abstracting beyond particular local contexts, toward a more comprehensive view. In the imperial sphere, a key element of legal reasoning was to seek out ways in which Muslim subjects of empire could be seen as a group comparable to Anglicans, Hindus, and others. One outcome of this work was conflation: making previously different areas of life and law equivalent and making possible a regime of law labeled "personal status," covering newly defined domains of marriage, the family, and private life. Here, too, critical roles were played by Muslims seeking to make themselves legible to imperial states and here, too, the effort at legibility was driven also by the varied interests of Muslim actors, not all of them aligned with the interests of the state.

Noting the indispensability of interlocutors, interpreters, and translators in the work of the state allows a rethinking of sovereign state acts, and of institutional change, that shows evidence of institutional borrowing, echoes of past forms and logics, and hybrid discourses of legitimacy. Against the totalizing vision that Scott attributed to the high modern state, therefore, is another way of seeing like a state, by necessity as well as by design: rather than state logic imposed from above, projecting a nonhuman scale onto political and social life, there is the more common pastiche cobbled together out of the reality of state projects built piece by piece, moment by moment. Political scientists and sociologists have discussed these phenomena under different headings: Streeck and Thelen have focused on "displacement" and "layering" in institutional change; ${ }^{\text {I }}$ Espeland and Stevens refer to the political work of commensuration, on its ability to "refract power in many ways," and on its key role in the making of modern subjects and states. ${ }^{\mathrm{I} 2}$ The anthropologist Susan Gal has commented on the phenomenon of "apparent familiarity" 
across institutions that comes into being through processes of standardization and fractal recursion along hierarchies and "axes of differentiation." ${ }^{13}$ Morgan and Campbell's exploration of delegated governance seeks to more precisely delineate the boundaries of the state between public and private actors. ${ }^{\mathrm{I}}$ In the case of British India, but also in nation-states that govern religious and cultural minorities, delegation delineated spaces of difference within the public sphere as well. The civil servants who served in these spaces were often privileged members of subject groups as well as state agents, part of the state because of their utility as middlemen, but subject to scrutiny and suspicion because of their status as members of target communities.

\section{THE BENEFITS OF LEGIBILITY: TRANSLATING IS LAM}

\section{IN COLONIAL COURTS}

Building on the analytic utility of the "many hands" paradigm, this chapter focuses on a legal judgment from British India, Queen-Empress $v$. Ramzan \& Ors (March 7, I88 5), a case that revolved around questions of how to define a Muslim, and who had the right to do so. ${ }^{15}$ This case bears the standard hallmarks of colonial processes of state-making: the work of defining the subjects of colonial authority, labeling the targets of administrative intervention, and arranging them according to a predetermined hierarchy of value, aimed at the production of social and political order for the colonial state. Yet here, where the matter at hand was the definition of "Muslim" with respect to worship in mosques, the judge himself - Syed Mahmood - was an Indian Muslim, and his role in deciding the case was explicitly tied to his knowledge of Islam. The judgment argued for a more prominent role for Islamic legal sources and reasoning within the legal system of British India, while at the same time working to make Islam legible in terms of Anglican Christianity. By virtue of their positions between the colonial state and its subjects, intermediary actors such as Mahmood played both a structural and an interpretive role; in doing its work, the state's many hands also routinely question its norms, interpret its knowledge in light of their own, and alter its course.

The original conflict referred to in the Ramzan case occurred in a mosque in Benares in I884: three men, among them Ramzan, entered the mosque and pronounced the word amin (amen) during prayer, a practice regarded by some other congregants as heterodox. ${ }^{16}$ A heated argument ensued about whether this was permitted during prayers, 
and the three were expelled from the mosque with the help of police and prohibited from entering again unless they recanted their position on this practice. Ramzan and the others were accused by other members of the mosque of not being Muslim, and of "the offence of insulting the religion of the Hanafia Musalmans" under Sections 297, 298, and 352 of the Indian Penal Code (I860). The Magistrate tried the case and found the three guilty under Section 296 ("disturbing religious assembly") and sentenced them to a fine or a month's imprisonment, based on the interpretation that saying amin loudly during prayers in a mosque constituted causing disturbance to religious worship and was therefore a criminal offence. Eventually the case reached the Allahabad High Court and was heard by a bench that included Judge Syed Mahmood (I850-1903). On the face of it, the case turned on whether saying amin could be understood to constitute an offence under the Indian Penal Code, of disturbing religious assembly; underneath the facts of the case were issues of congregational politics, of possible financial misconduct, and of doctrinal differences used to draw a line between those who were considered Muslim and those not. Mahmood was ultimately to argue that a Muslim had the right to worship in a mosque "according to his tenets," and that it was not a criminal offence to say amin in a mosque. ${ }^{17}$

It would seem a small point, a small case, except that Mahmood built upon the facts of the case a foundation for enlarging the scope of application of Islamic law in British India, based on the argument that "Muhammadan Ecclesiastical Law" needed to be consulted in cases such as these. In fact, he argued, "the Muhammadan Law shall be administered with reference to all questions regarding 'any religious usage or institution." ${ }^{18}$ The manner by which he made this argument was to render Islam and Muslim worship comparable to Anglican Christianity. Through cases such as Ramzan, the "Indian Muslim" was made legible as a category in law comparable to the "Christian," as was the "Hindu"; the mosque and temple were understood as spaces equivalent to churches, and the activities performed in them categorized as "worship." Cases such as these allow a closer look at the involvement of local agents in epistemic and political processes, delineating processes through which the state sought to produce comparability and ubiquity across its domains, and suggesting that these processes were themselves translative and comparative, dialogical rather than unidirectional. This is not to say that the political economy of colonial institutions was balanced between colonizer and colonized, nor that outcomes were egalitarian; it is, however, to see 
these middlemen as themselves having interests and worldviews that remained important even as they did the work of the state they served.

Further, a closer examination of these cases shows that these middlemen - not merely translators, scribes, and expert witnesses producing raw material for British adjudication but judges and lawyers with delegated responsibility for the making of British justice - played critical roles in making space for "native" sources of law and legal reasoning. In Ramzan, the judge argued against the established hierarchy and practice of English common law in British India, in favor of a broader application of Islamic law. Intrinsic to the making of British colonial law were Indian judges whose positions between colonizer and colonized gave them the legitimacy and knowledge to perform their functions, an interest in expanding the space allowed for certain "native" institutions beyond what the colonial state envisioned, and a desire to make these institutions legible and credible within the colonial context. From the perspective of law and its politics, even the state's "projection" of a unified image required a multiplicity of lenses and optics, many hands from the start. ${ }^{19}$ Rather than seeing this multiplicity as deviation from the norm of the state, dysfunction, or malfunction, the many hands and eyes of the colonial state helped produce durable transformations in law and society, in what it meant to govern Muslims, and in what it would mean to be Muslim.

By the middle of the nineteenth century, British colonial rule in India depended - more and more openly - upon the participation of Indians in administrative and institutional capacities. This dependence was twofold: first, on the lack of material capacity to administer a huge state with a relatively small number of British officials, and second, on the vision of legitimate colonial governance as proxy and tutelage for native rule. When the British Crown took over the government of India from the East India Company in 1858 , the symbolic importance of rule of law, and the need to demonstrate the legitimacy of British rule in India, gave local intermediaries and authorities a critical role to play in indirect rule. ${ }^{20}$ With the I 857 revolt clearly in mind, religion was marked out as a domain needing particular care. ${ }^{2 \mathrm{I}}$ The role of Indians in the British colonial state machinery was critical, and their difference from the colonial administrator was a key component of their utility and visibility in the state.

The aftermath of the revolt removed many aristocrats, religious leaders, and elites associated with long-standing institutions of Indian Islam from positions of influence in British India. This cleared the field for a rising class of British-educated men such as Syed Ahmad Khan (I8I7-I898), Faiz Badruddin Tyabji (เ844-1906), Syed Ameer Ali 
(1849-I928), Abdur Rahim (I867-I962), and Asaf Ali Asghar Fyzee (I899-I98I) to become interlocutors between the colonial state and Indian Muslims. ${ }^{22}$ Judge Mahmood was the son of Syed Ahmad Khan, a close ally of the British in India as well as a fierce proponent of the advancement of the Indian Muslim community. The first Indian Muslim appointed to a High Court judgeship in British India, Mahmood studied in schools established by the British in India before receiving a scholarship from the British to study law in England. Mahmood was admitted to Lincoln's Inn in I869 and soon after became the first non-European member of the Allahabad Bar. ${ }^{23}$ The institutionalization of Islamic law within the ambit of state courts and the increasing reliance on the logics and language of colonial legality meant that Muslim lawyers trained in European law, such as Syed Mahmood, began increasingly to play important intermediary roles in interpreting Islamic law within the legal idiom of the colonial state. These lawyers performed their functions assured of the basic unassailability of English legal logic, largely untrained in matters of fiqh (Islamic jurisprudence) and Islamic legal practice, yet they saw the courts and legal processes themselves as venues for the advancement of Muslim identity and strategy.

Muslims newly incorporated into the legal hierarchy of British India were not only called upon to judge matters of the law relating to religious usages and institutions, they were also often pressed to define who a Muslim was, and what the proper conduct of Muslim worship and religious observance should be. In Ramzan, as in other cases, Judge Mahmood was called into the case because he was Muslim and knew the "Muhammadan Ecclesiastical Law." When the case reached the Allahabad High Court, Mahmood noted, "in view of the peculiarities of the question with regard to the right of worshipping in mosques possessed by Muhammadans, my learned brother referred the case to a Division Bench, of which, at his suggestion, and with the approval of the learned Chief Justice, I was to be a member." ${ }^{24}$ Once on the Bench, at several points, Mahmood questioned or steered the process of the trial. From the Division Bench, the case was referred to the Full Bench "to obtain an authoritative ruling on the question"; from the Full Bench, Mahmood reserved his order, refusing to either concur in or dissent from the decision to uphold the conviction.

For Judge Mahmood, the Bench ruling was problematic not only because of the absence of "the authorities of Muhammadan Law" in the details and reasoning of the judgment, but because of the general principle upon which this absence was justified. "If it is conceded that the 
decision of this case depends (as I shall presently endeavor to show it does depend) upon the interpretation of the Muhammadan Ecclesiastical Law, it is to my mind the duty of this Court, and of all courts subordinate to it, to take judicial notice of such law." ${ }^{25} \mathrm{He}$ finally provided a written dissenting opinion that was printed in the India Law Report of 1885 . After I 875, cases published in the India Law Reports were binding on all subordinate courts in British India; the Reports published about 300 of Judge Mahmood's opinions, lengthy pieces of legal scholarship that also included, translated, and interpreted Arabic jurisprudential sources, thereby making them usable throughout British India as sources of law. ${ }^{26}$ His opinion in the Ramzan case was a separate ruling, dissenting from the judgment made by the full bench, but became one of the mostcited and influential rulings about the use of mosques, disputes over the diversity of Muslim conduct, and the right of Muslims to worship according to their conscience. In later years, this judgment would also be cited to defend the rights of members of minority sects of Islam to claim their right of access to mosques, and their rights to be treated as Muslims under the law. ${ }^{27}$

Judge Mahmood argued that the matter of the case, which was "the right of a Muhammadan being able to pray in a mosque according to his tenets," required reference to the "express guarantee given by the Legislature in Section 24 of the Bengal Civil Courts Act (VI of I87I), that the Muhammadan law shall be administered with reference to all questions regarding 'any religious usage or institution." Mahmood argued that, by this reasoning, even courts applying criminal law should take notice of the interpretation of "Muhammadan Ecclesiastical Law" as part of "the rules of civil law":

That the application of some of the sections of the Indian Penal Code depends almost entirely upon the correct interpretation of the rules of civil law, cannot, in my opinion, be doubted ... but for this principle, the rules of the Penal Code would in many cases operate as a great injustice. ${ }^{28}$

Further, Judge Mahmood argued that Muhammadan law should not be equated with foreign law in cases such as these, providing a potentially expansive rationale for reference to Islamic legal sources more generally:

I hold therefore that in a case like the present ... Muhammadan Ecclesiastical Law ... is not to be placed upon the same footing with reference to this matter as any foreign law ... and it follows that I can refer to the Muhammadan Ecclesiastical Law for the purposes of this case, notwithstanding the absence of any specific evidence on the record regarding its rules. ${ }^{29}$ 
Mahmood used the institution of precedent and the citational practices of British law to bring Islamic legal logic and texts back into the legal system of British India. His legal legacy sheds some light on how Muslim elites navigated colonial institutions of law to bring shar'i content back into the system. Whereas the earlier replacement of fiqh experts with legal texts in colonial law courts served to reify Islamic law into a limited and somewhat static domain, Muslim lawyers and judges working in the colonial law courts in the late-nineteenth and early-twentieth centuries found ways of turning this reliance on text and precedent to their advantage. ${ }^{3 \circ}$ These elites actively participated in the new institutions of colonial law, and their presence provided a visible signal of the legitimacy and justice of the colonial state, at the same time that their actions within these institutions continued to negotiate the state's boundaries. In particular, despite their acceptance of the forms of colonial rule, its logics, and its jurisdiction, they continued to negotiate the boundaries of Islamic law and struggled to retain shariah content and logics, using the new institutional avenues of the colonial law system.

\section{THE EFFECTS OF TRANSLATION: "SCRIPTURALIST ISLAM"}

Yet the participation of British-trained lawyers and judges in the courts of British India also profoundly altered the content and meaning of Islam in the legal system. It is here that a focus on the many hands of the state also allows deeper exploration into its many optics - the institutional inclusion of Indian Muslims in the legal system of British India made possible a renegotiation of the place and content of Islam in the law, but their inclusion also transformed the ways in which Islam would be understood, both by the state and by Muslims themselves. The optics of the state depend upon the perceptions and strategies of its key agents: here, Judge Mahmood translated the case of Ramzan according to the vernacular of British India, that included a value system based upon Anglican Christianity and a legal hierarchy of canonical texts, all the while acknowledging an underlying tension with the methods and logic of Sunni Islamic jurisprudence. Ultimately, the work of British-trained lawyers and judges such as Mahmood, working within the system to enlarge the jurisdiction of Islamic law, would bring about a system of law that prioritized canonical text over learned debate, precedent over judicial reasoning, and located the proper domain of Islam over the narrower arena of family law and ritual matters. This "scripturalist Islam" ${ }^{31}$ translated Islamic legal institutions, logics, and texts into the 
idiom of Anglican Christianity, and Islamic law into the language and order of common law, and would in time help to answer an expectation among British judges and jurists that Islam in a Muslim state could occupy the same place as Christianity in England.

Mahmood was neither a scholar of fiqh nor a lawyer trained in Islamic adjudication, rather, he was "an Islamic modernist committed to individual interpretation of sacred texts with limited attention to the historical traditions of commentators." ${ }^{22}$ Instead of fiqh experts serving as advisors and witnesses, increasingly, British-trained Muslim judges functioned as knowledgeable arbiters of Islamic legal issues in the courts of British India and generated a significant amount of authoritative law in multiple arenas - including who should be considered a Muslim, how worship in a mosque should be conducted, and how to understand the relationship between Muslim practice in India and the authoritative texts of Islamic law. Like Judge Mahmood, they brought with them a new orientation toward the sources and logic of the shariah and an acceptance of the jurisdictional divisions and some of the assumptions of British law in India. This new orientation included a reliance on textual sources, a preoccupation with making Islamic law legible in British terms, and an interest in articulating the logic of Islamic jurisprudence in ways that would endure in the British system. A primary element of the reorientation of the practice of Islamic law in the courts of British India was the demonstration of a methodology for determining the content of Muslim practice, tradition, and orthodoxy, and to make that methodology both usable in the courts and relatable to other sources of colonial law. To this end, having made an argument that the Muhammadan Ecclesiastical Law must be referred to in cases of this type, it remained the task of the judge to determine which texts and practices mattered. Mahmood determined that "orthodox" in this case referred to Sunni practice and the schools of Sunni jurisprudence, despite the presence of non-Sunni Muslims in India. Within this orthodoxy, he arranged an order of authoritative legal texts, situating particular texts of the Sunni Hanafi school of jurisprudence, the British translation and compilation of the Hidaya primary among them, at the top of the hierarchy of jurisprudential sources to consult. ${ }^{33}$

A second element of this reorientation was translation, making Islam and the content of Muslim religiosity fully legible in Anglo-Christian terms. Mahmood's arguments about the relationship between authoritative Islamic texts, Muslim practice, and orthodoxy were based on an assumption that Islam is comparable to Christianity, Anglicanism in 
particular, and that his audience would be persuaded to his point of view more readily if they understood this comparability. He referred from the beginning of his judgment to "the Muhammadan Ecclesiastical Law," 34 which in his argument means the "Koran," "Sunna" and the teachings of the four schools of Sunni fiqh; at other points he referred to four "orthodox schools of Muhammadan Ecclesiastical Law," thereby equating Sunni fiqh with church law. He referred to mosques as having "congregations" and being "consecrated"; in attempting to determine whether the alleged offences were actually committed during worship, he compared Muslim prayers with the reading of the Nicene creed. The word amin itself "has been adopted in prayers by Muhammadans as much as by Christians." ${ }^{5}$ The only point of distinction he drew was to comment that unlike "an ordinary Christian church," mosques were also places for "religious and moral teaching and discussion." ${ }^{36}$

Mahmood was careful in his jurisprudence to preserve some elements of divergence between Islamic jurisprudence and British - he acknowledged the prevalence of debate in Islamic jurisprudence and the need for consensus on matters not clearly enunciated in the Koran, and went on to list the opinions of jurists in the Hanafi and Shafi'i school, noting that while the Malikis and Hanbalis would concur on this issue, their opinions were not pertinent because "their followers do not exist in British India." ${ }^{37}$ Mahmood also referred to the wider world of Muslim practice, tying the Muslims of India to a hinterland beyond British control, referring for example to the practices of Muslims at the Kaaba ("the greatest mosque in the world") and "all the Muhammadan countries like Turkey, Egypt, and Arabia itself," where the practice of saying amin was varied but not controversial. Finally, and with prescience, Mahmood's judgment made clear that determinations as to the proper and lawful conduct of Muslim worship needed to be sensitive to the rights of the minority within a religious group. He argued that the Public Prosecutor's opinion that "the mere fact of the disturbance being caused to the religious assembly is sufficient to constitute the offence" ${ }^{8}$ placed undue emphasis on Section 296, valuing maintenance of peace above the right of individuals to worship according to their tenets.

Mahmood's arguments and his method of reasoning the case show a keen awareness of the potential breadth of his audience, and they allow a glimpse into the "intimate interaction of legal administration and indigenous identity formation" that helped inscribe "scripturalist Islam" in the Muslim state. ${ }^{39}$ In doing so, they help show that indigenous identity formation was a process in which particular local elites played critical 
mediating roles, and they reveal the logic by which scripturalist Islam appealed to both Muslims and British actors in the late nineteenth century. ${ }^{40}$ They also show that this translative logic was seen to be enormously important for communicating the content and meaning of Islamic jurisprudence to a common law audience. In Mahmood's words, "I have mentioned all this in order to render intelligible what I am going to say presently," with regard to the content of the case, but the need for intelligibility, when articulated within the medium of the law, also had far-reaching effects for Islamic law itself.

\section{IMPERIAL CONFLATIONS: PERSONAL STATUS LAW AS "RELIGION"}

British-trained Muslim lawyers such as Judge Mahmood, working within the colonial state, helped to redefine the shariah as Muslim personal law through the legislation and precedential systems of the courts of British India. ${ }^{4 \mathrm{I}}$ This had the effect of turning a colonial domain of governance into an arena for the assertion of a distinct Indian Muslim community interest; however, it also fundamentally altered the scope and meaning of Islamic law in British India. ${ }^{42}$ From a wide-ranging system of laws and institutions with jurisdiction over politics, society, and the state, the shariah redefined as laws of Muslim personal status came to govern only matters of marriage, divorce, religious endowments, and ritual observance. Cases such as Ramzan show how, from a narrowly prescribed realm of colonial law, Muslim judges and lawyers worked through common law processes and reasoning to expand the jurisdiction of Islam. They did so, however, in ways that were legible to the colonial state, and translatable within the idiom of colonial law. Across the British Empire, Muslims attempting to make themselves legible to the colonial state were using the vehicle of law to assert a Muslim interest; by the end of the nineteenth century, in India, Egypt, Malaya, and elsewhere, diverse regimes of local and Islamic legal practices were rendered legible to the empire as "Muslim personal status law."

From the perspective of the rising class of Muslim administrative and political elites in British India, the codification and regularization of laws governing Muslim life represented a number of opportunities: to widen the space allowed for native practices within British law in India, to give some shariah practices the status of established law, to clarify and regularize that law, and to make possible their own participation and intervention in this legal sphere - as lawyers, authoritative interpreters, advocates, and 
members of a rising "Indian Muslim" community. From the perspective of British colonial administrators and judges in India, the codification and regularization of laws relating to Muslims reduced confusion in the courts and made the administration of justice more regular and reliable, in particular by removing the amount of leeway provided to expert witnesses and to interpretation of Islamic jurisprudential sources. Codification and regularization also carried the added benefit of reducing the complexity and diversity of practices and authoritative rules that might have applied to native subjects, by applying one marker of identity above all others religion. The Muslims of India would have one kind of law applied to them, regardless of their differences of language, region, sect, or traditional practice; a similar unification would apply to the Hindus and Christians of India. British conceptions of "communities" divided by religious affiliation after I 857 in India prompted law reforms based on legal pluralism; after the $\mathrm{I} 88 \mathrm{os}$, in particular, claims for political representation by Indians came to be articulated in terms of communal representation. ${ }^{43}$

As conflicts in the courts over the proper interpretation of Islam continued, the effort to communicate Islamic law and Muslim practice as comparable to, and legible in terms of, Christianity also contributed to an understanding of the religions of British India as occupying similar spheres of life and representing equivalent confessional communities. The administration of justice in the courts and the legislative process reinforced the understanding that Indians were divisible into two fundamental communities - Hindu and Muslim - and that politics could not but be structured along these lines. Legal reforms in the early twentieth century (I909 Indian Councils Act, known as the Morley-Minto reforms), articulated as giving over more power to natives in government, also responded to concerns among Muslim elites that their interests be protected as minorities through electoral representation. The colonial category of personal status law - law applying to subjects based upon confessional identity - therefore became conflated, in British India, with a domain of Islamic law first defined by the colonial state, but later taken on and expanded by Muslim elites themselves - laws of marriage, the family, and ritual observance. This conflation further reinforced delineations of public and private domains in the administration of law and the governance of religion, such that the private would overlap with the religious, and the religious with the communal. From the end of the nineteenth century onward, moves to increase Indian participation in government also further entrenched the dichotomy and tension between Hindu and Muslim communities. 
Looking beyond India also helps make clear how colonial understandings of Islam and Muslim subjects were shaped by imperial experiences and concerns, and how empires learned from other empires how Muslims were defined and how to govern them. At the same time Britain's Muslim subjects in India were working to make themselves legible to the colonial state as a community based on confessional identity, in Egypt, Muslims who had previously been governed by Ottoman and French law were coming under the rule of the British Empire. The meeting, in Egypt, of British common law approaches to the governing of Muslims with Ottoman and French civil law practices and institutions contributed further to the conflation of personal law with personal status. ${ }^{44}$ The movement of colonial officials between British India and Egypt in the later decades of the nineteenth century was also a significant network for the importation of "Indian" ideas into the administration of Egypt. ${ }^{45}$ In Egypt, all this resulted, at the end of the nineteenth century, in efforts at legal reform in which Islamic legal content would largely be elaborated within the confines of "al-Ahkam al-Shar'iyya fi al-Ahwal alShakbsiyya," "shari'ah laws in matters of personal status," referring largely to family law. ${ }^{46}$

In Egypt, the French state inherited an Ottoman system that differentiated among imperial subjects by confessional identity, drawing from the Ottoman imperial system of millet (in which recognized minority groups in the Ottoman Empire, such as Christians and Jews, could govern according to their own laws) and from the system of mixed and native courts imposed by European powers upon Egypt. Egyptian elites redefined a realm of Islamic legal practice that would overlap with these inherited legal classifications and, like their counterparts in India, sought to define this realm in order to preserve the latitude of Islamic legal reasoning while negotiating the boundaries of the colonial state. By the time the British took over the administration of Egypt, they inherited an evolving imperial consensus that communities were divided by religious identity, that at the heart of religious identity were matters of ritual and the family, and that both ritual and family matters were to be understood as private matters.

Across the British imperial world during this period, in fact, there were increasing similarities within Muslim communities in response to the encroachment of British law. ${ }^{47}$ These strategies were twofold: local Muslim elites often accepted, and at times expanded upon, colonial categorizations of Islamic law as pertaining only to a narrow private domain of family, personal status, and ritual worship, but at the same 
time they continued to assert and renegotiate the proper division between matters of Islam and matters of the state, including the meaning and scope of Islam as articulated by British colonial law. ${ }^{4}$ They mark a convergence between previously quite separate logics and institutional bases, due to the assumption by imperial officials that the principles for governing Muslims in India would translate to the Muslims of Egypt or Malaya, and to an increasing interest among varied Muslim elites to articulate Islam in ways that would be legible to the British, and translatable across multiple domains. Over the longue durée of British colonialism and imperialism, the religious and the private realm were co-constituted over the Muslim family, in the institutionalization of personal status law. ${ }^{49}$ In British India in the I770s, personal law referred to differential jurisdictions, as laws applied depending upon membership in religious communities: Hindu laws for Hindus, Muslim laws for Muslims. By the time the formulation was instituted in Egypt as al-Ahkam al-Shar'iyya fi al-Ahwal al-Shakhsiyya, the "personal" in personal law carried two meanings - the first tied to communal affiliation, the second to the individual as a unit of administrative control, recognizable across the empire by the signifier "Muslim." 50 This understanding of Islamic law as centrally focused on family and private matters, and of religious identity as centrally located in the domains of marriage, gender, and ritual observance, endures in the legal systems of many contemporary Muslim and non-Muslim states.

\section{TRANSLATIONS AND CONFLATIONS IN THE MAKING OF THE MUSLIM STATE}

The routinized and iterated work of making legibility at various levels of the state, made possible and ubiquitous through the translative and comparative functions of courts and jurisprudence, contributed to the making of the Indian colonial state as well as the British imperial state, and on the way contributed to a radical transformation of Islamic law and its relation to Muslim life. A closer look at legal institutions, often understood as the linchpin of state power and sovereignty, reveals the work of middlemen whose roles were indispensable to the legitimacy, authority, and functioning of the state precisely because of their positions as part of the communities they helped govern. Yet these middle positions also provided state actors with the resources and interest to advocate for and realize change in state institutions, toward the incorporation of alternate (and sometimes conflicting) sources and logics of law and practice. The agency of the state, when the work of middlemen such 
as Muslim judges in British India is taken into account, is complex, working to change state logics at the same time that it reaches toward the extension of state power. State agency, enacted through networks of law, religion, and culture, also extends beyond its borders, articulating areas of contrast and familiarity across imperial, regional, and global polities and further reinforcing categorical conflations such as that between religious law and personal law, family law and private law.

Rather than assuming either the vision of the colonial state or its hierarchies, this chapter has sought to explore the implications of many eyes, many optics, many voices of the state, in the making of information, rules, and law. The preoccupation of the state has, by and large, not been to suppress these multiplicities, but to translate and compare among them. To see like a state, this chapter has argued, especially like a colonial and imperial state, is to seek out comparison and translation, areas of legibility that may then become bases for manipulation as well as extrapolation. While it is often assumed that the state dictates a vision from above that its agents seek to realize, a closer exploration of the work of middlemen and intermediaries suggests that this drive for comparison was also generated by the need for legibility from below. Further, this drive for legibility was itself motivated by interests to renegotiate the knowledge, norms, and mission of the state. When the imperial state is held distinct from the colonial state, it also becomes clear that states often see through each other's eyes, inheriting institutions, languages, and practices from each other and reworking them in multiple venues. The many hands of the state do not merely point us in the direction of rethinking the state's agency or its unity as an actor; they also indicate the work of multiple interpreters, interlocutors, and agents as the work of the state.

\section{Notes}

Thanks are due to Ann Orloff and Kimberly Morgan for their comments on a number of drafts of this chapter, and to Kapil Raj, Sanjay Subrahmanyam, and colleagues at the École des Hautes Études en Sciences Sociales (EHESS, Paris) for their very constructive and helpful comments on portions of this work, presented as part of my tenure as Professeur Invitée at EHESS (Spring 2015).

I James Scott, Seeing Like a State: How Certain Schemes to Improve the Human Condition Have Failed, (New Haven: Yale University Press, I999), I83.

2 Ranajit Guha, Dominance without Hegemony: History and Power in Colonial India (Cambridge: Harvard University Press, 1998).

3 Talal Asad, Genealogies of Religion: Discipline and Reasons of Power in Christianity and Islam (Baltimore: Johns Hopkins University Press, I993). 
4 Winifred Sullivan, The Impossibility of Religious Freedom (Princeton: Princeton University Press, 2005); Elizabeth Hurd, The Politics of Secularism in International Relations (Princeton: Princeton University Press, 2008); Wael Hallaq, The Impossible State: Islam, Politics, and Modernity's Moral Predicament (New York: Columbia University Press, 2013).

5 Discussing contemporary religion and fundamentalisms, Olivier Roy has referred to the process in which the state standardizes religions as "formatting." Holy Ignorance: When Religion and Culture Part Ways (New York: Columbia University Press, 2010), I87-9I.

6 See Chapter I 5. Exceptions include Lauren Benton, A Search for Sovereignty: Law and Geography in European Empires, I400-I900 (Cambridge: Cambridge University Press 2010).

7 Michel de Certeau, The Practice of Everyday Life (Berkeley: University of California Press, I984); Joel Migdal, State in Society: Studying How States and Societies Transform and Constitute Each Other (Cambridge: Cambridge University Press 200I); Bruno Latour, The Making of Law: An Ethnography of the Conseil d'Etat,(Cambridge: Polity Press 2009); James Mahoney and Kathleen Thelen, eds., Explaining Institutional Change: Ambiguity, Agency, and Power (Cambridge: Cambridge University Press 2010).

8 Chapter I 5 .

9 Chapter I 5 .

Io Philip Abrams, "Notes on the Difficulty of Studying the State," Journal of Historical Sociology I, no. I (I988 [1977]): 68.

I I Beyond Continuity: Institutional Change in Advanced Political Economies (New York: Oxford University Press 2005), I9-24.

I 2 "Commensuration as a Social Process," Annual Review of Sociology, 24 (I998): 332, 339.

I 3 "Sociolinguistic Regimes and the Management of 'Diversity," in Language in Late Capitalism: Pride and Profit, eds. Alexandre Duchene and Monica Heller (New York: Routledge), 22-42.

I4 Kimberly J. Morgan and Andrea Louise Campbell, The Delegated Welfare State: Medicare, Markets, and the Governance of Social Policy (New York: Oxford, 20II).

I 5 Indian Law Reports Allahabad series (Government Press, I 885), 46I.

I6 Alan Guenther, “A Colonial Court Defines a Muslim," in Islam in South Asia in Practice, ed. Barbara Metcalf (Princeton: Princeton University Press, 2009), 293-304.

I7 Indian Law Reports Allahabad series (Government Press, I885), 46I, at I3.

I 8 Indian Law Reports Allahabad series (Government Press, I885), 46I, at 7.

I9 Migdal, State in Society.

20 Karuna Mantena, Alibis of Empire: Henry Maine and the Ends of Liberal Imperialism (Princeton: Princeton University Press, 2010).

2I Iza Hussin, The Politics of Islamic Law: Local Elites, Colonial Authority and the Making of the Muslim State (Chicago: University of Chicago Press, 2016).

22 Asaf Fyzee, Outlines of Muhammadan Law (Delhi: Oxford, I974), 5 I.

23 The Honourable Society of Lincoln's Inn, through which barristers would be called to the English Bar. Guenther, "Colonial Court," 294. 
24 Indian Law Reports Allahabad series (Government Press, I885), 46I at I.

25 Indian Law Reports Allahabad series (Government Press, I885), 46I at 7.

26 Guenther "Colonial Court," 295. Guenther argues convincingly that the Law Reports Act of 1875 had the unintended consequence of creating a new source of Muslim law.

27 Ata-Ullah v. Azim-Ullah, Indian Law Reports Allahabad series (Government Press, I890), 494; Hakim Khalil Ahmad v. Malik Israfi, Patna Law Journal (I9I7), IO8.

28 Indian Law Reports Allahabad series (Government Press, I885), 46I at 7.

29 Ibid.

30 Guenther, "Colonial Court," 293-304.

3 I Michael Anderson, "Islamic Law and the Colonial Encounter in British India," in Institutions and Ideologies: A SOAS South Asia Reader, eds. David and Peter Robb Arnold (London: Curzon, I993), I65-85.

32 Guenther, "Colonial Court," 294.

33 The Hedaya was Charles Hamilton's (d. I792) translated and truncated version of a key compendium of jurisprudence from the Hanafi school of law, al-Hidaya [The Guide], used as an authorized source of Islamic law in the courts of British India. Mahmood cited Hamilton's preface to his "translation of the Hedaya," which Mahmood defines as "the most celebrated textbook of the Hanafi school of law," ( $\mathrm{I}_{3}$ ) before discussing the conflicting opinions of commentators found within the hadith collections of Bukhari and Muslim.

34 Indian Law Reports Allahabad series (Government Press, I885), 46I at I.

35 Ibid., $46 \mathrm{I}$ at II.

36 Ibid., $46 \mathrm{I}$ at $\mathrm{I} 7$.

37 Ibid., 46I at $\mathrm{I} 3$.

38 Ibid., 46I at 18 .

39 Anderson, "Islamic Law."

40 Cf. Ebrahim Moosa, "Colonialism and Islamic Law," in Islam and Modernity: Key Issues and Debates, eds. Masud, Salvatore, and van Bruinessen, I 66.

4I Hussin, Politics of Islamic Law.

42 Scott Kugle, "Framed, Blamed and Renamed: The Recasting of Islamic Jurisprudence in Colonial South Asia," Modern Asian Studies 35, no. 2, (May 200I): 257-3I3.

43 Hussin, Politics of Islamic Law.

44 Guido Tedeschi, "Personal Status and Statut Personnel," McGill Law Journal I 5 , no. 3 (I969): $452-64$.

45 Robert L. Tignor, "The 'Indianization' of the Egyptian Administration under British Rule," The American Historical Review 68, no. 3 (April 1963): 636-6I; Thomas Metcalf, Imperial Connections: India in the Indian Ocean Arena, I860-1920 (Berkeley: University of California Press, 2008).

46 Hussin, Politics of Islamic Law.

47 Ibid.

48 These similarities mark an increase in exchanges between South Asia, the Middle East, and Southeast Asia, facilitated by technological change and the 
colonial peace, but also by the opportunities these afforded to existing Muslim networks of learning, pilgrimage, and trade.

49 Hussein Agrama, writing about Egyptian law, relates the formulation of personal status to the problem of public order in Egypt, describing the I 897 reform of the Shariah courts as having "brought into affinity a new set of concepts and affects - family, intimacy, publicity, secrecy, and public order through which the domains of public and private could be mutually entailed and authorized by the state." Questioning the Secular (Chicago: University of Chicago Press 2012), I00.

50 Hussin, Politics of Islamic Law. 